\title{
Epidemiological analysis of the reported cases of covid-19 in the municipality of Gloria de Goitá, in the state of Pernambuco, in the period of 2020
}

Júlio César da Silva Bruce ${ }^{1}$, Andrezza Fabianni Pedrosa dos Santos Lima ${ }^{2}$, Emilly Tainá Batista da Silva $^{3}$, Emivaldo Batista da Silva ${ }^{4 *}$, Joana Bulhões Alvares da Silva Lima ${ }^{5}$, Ana Santana da Silva ${ }^{6}$, Emanuella Souza Bacelar ${ }^{7}$, Adriana de Andrade de França Santos ${ }^{8}$, Elymax Miquéias Lima Teodósio dos Santos ${ }^{9}$, Jessikele Gonçalves Bezerra ${ }^{10}$, Maria Talita Bernardo Silva ${ }^{11}$, Thacyla Emanuely Santos Alves $^{12}$, Emanuella Barros de Souza Oliveira Alvares ${ }^{13}$

1,4,5,6,7,9, Department of Pharmaceutical Sciences, University Center of Vitória de Santo Antão - (UNIVISA) Vitória de Santo Antão, Brazil. 2,10,11,12 Department of Nutrition, University Center of Vitória de Santo Antão - UNIVISA, Vitoria de Santo Antão

8 Department of Biomedicine, Post-Graduation in Clinical Cytology (FACEAT- Faculty Center for Advanced Studies and Technology) Recife - PE

3 Department of Biomedicine, Post-Graduation in Laboratory Clinical Microbiology (ASCES- UNITA) Caruaru - PE

13 Department of Biology, Center for Biological Sciences, Professor of the Degree Course in Biology, University Center of Vitória de Santo Antão (UNIVISA), Vitória de Santo Antão, Brazil

E-mail adresses: julio.2017186009@univisa.edu.br1 (Júlio César da Silva Bruce), andrezzafpslima@hotmail.com2 (Andrezza Fabianni Pedrosa dos Santos Lima), emilly.taina@hotmail.com3 (Emilly Tainá Batista da Silva), emivaldobatista4@gmail.com4 (Emivaldo Batista da Silva), joanafarmacia2018@gmail.com5 (Joana Bulhões Alvares da Silva Lima), ana.202121034@univisa.edu.br6 (Ana Santana da Silva), mannubacelar@gmail.com7 (Emanuella Souza Bacelar), adriana2806franca@gmail.com8 (Adriana de Andrade de França Santos), elymaxmiqueias19@gmail.com9 (Elymax Miquéias Lima Teodósio do Santos), jessikeleg@gmail.com10 (Jessikele Gonçalves Bezerra), mariatalita965@outlook.com11 (Maria Talita Bernardo Silva), emanuella.barros@hotmail.com12 (Emanuella Barros de Souza Oliveira Alvares).

${ }^{*}$ Corresponding author

\section{To cite this article:}

Bruce, J.C.S.; Lima, A.F.P.S.; Silva, E.T.B.; Silva, E.B.; Lima, J.B.A.S.; Silva, A.S.; Bacelar, E.S.; Santos, A.A.F.; Santos, E.M.L.T.; Bezerra, J.G.; Silva, M.T.B.; Alves, T.E.S.; Álvares, E.B.S.O. Epidemiological analysis of the reported cases of covid-19 in the municipality of Gloria de Goitá, in the state of Pernambuco, in the period of 2020. International Journal of Sciences. Vol. 3, No. 1, 2022, pp.74-78. ISSN 27635392 .

Received: 11 24, 2021; Accepted: 12 26, 2021; Published: 01 15, 2022

\begin{abstract}
In December 2019, pneumonia associated with the new coronavirus appeared in Wuhan, in the first 30 days China recorded 11,821 cases and 259 deaths. This research aims to analyze the reported cases of Covid-19 in the municipality of Glória do Goitá, in the state of Pernambuco, in 2020. This is a descriptive study of documentary research and analysis of secondary data of epidemiological surveillance of the Epidemiological Bulletin of December 28, 2020, conducted in the period of May 2020, in the municipality of Glória do Goitá, in the State of Pernambuco. We confirmed 454 cases of the disease, 237 (52\%) males have a higher percentage when compared to females, $217(48 \%)$ recovered, $19(63 \%)$ deaths. According to data published in Bulletin No. 32 COVID-19 Municipal Health Department 2020, the month of June presented a total of 85 recovered, followed by the month of December, to which it presented a total of 78 recovered. And in relation to deaths recorded during the year 2020 , the month of May has the highest mortality rate, 10 deaths, while the months of September and October do not present records of death by Covid-19. Confirming a pattern of infection experienced throughout the national territory.
\end{abstract}

Keywords: Coronavirus. Pathophysiology. Sars-Cov-2. 
2 Bruce, J.C.S.; Lima, A.F.P.S.; Silva, E.T.B.; Silva, E.B.; Lima, J.B.A.S.; Silva, A.S.; Bacelar, E.S.; Santos, A.A.F.; Santos, E.M.L.T.; Bezerra, J.G.; Silva, M.T.B.; Alves, T.E.S.; Álvares, E.B.S.O. Epidemiological analysis of the reported cases of covid-19 in the municipality of Gloria de Goitá, in the state of Pernambuco, in the period of $2020 \ldots$

\section{Introduction}

In December 2019, pneumonia associated with the new coronavirus evidenced in the period 2019 (Sars-Cov-2) appeared in Wuhan, China, which caused an inflammatory response in the body with mostly respiratory signs and symptoms (CHEN et al., 2020).

In the first 30 days, China recorded 11,821 cases and 259 deaths. During The Month of January, the disease was evidenced in other countries of the Asian, European and American continents of Asia, Europe and North America. Also this month, precisely on January 30, 2020, the World Health Organization (WHO) declared an Emergency situation in Public Health of International Importance (ESPII). In a scenario with more than 110,000 cases distributed in 114 countries, who deliberated the pandemic communiqué on March 11, 2020 (WANG; TANG; WEI, 2020).

In Brazil, the first cases were confirmed in February, and several actions were implemented in order to contain and mitigate the progress of the disease. On February 3, 2020, the country declared a Public Health Emergency of National Importance (ESPIN) (BRASIL, 2020).

The pathophysiology of the disease is related to the entry into the alveolar epithelium of Sars-Cov-2 and the consequent immune reaction of the host to this virus. In the most severe forms of the disease, it is possible to observe a systemic inflammatory response that results in increased release of cytokines. Such inflammation is capable of generating prothrombotic endothelial changes (ZHOU et al., 2020).

The increase in fibrinogen and D-dummer levels is one of the causes of hypercoagulation, in addition to prolongation in the prothrombin period (TAP) and in the period of activated partial thromboplastin (TMP), mild thrombocytopenia, associated with altered levels of factor VII and Von Willebrand factor (ORSI etal., 2020).

In addition, patients infected with the new coronavirus may present disorders correlated with the coagulation process, thus increasing the risk of thrombosis. Being this process resulting from a clinical condition I that occurs the appearance of one or more blood clots in a deep vein of the patient's body. Usually thrombosis may arise in the lower leg, thigh, or pelvis. This clot may run through the blood vessels of the patient's body, reaching the lungs, causing the death of the patient (CHEN et al., 2020).

It is of paramount importance to point out that elderly or individuals with comorbidities, such as: diabetes, cardiovascular, maternal and respiratory diseases tend to progress to the most aggressive form (GUO et al., 2020). Epidemiological records in the municipality of Glória do Goitá, Pernambuco, indicate the 30 individuals who died, these had confirmed comorbidities, such as: hypertension, diabetes, chronic cardiovascular disease, smoking, chronic kidney disease, asthma, obesity, alcohol consumption, chronic liver disease, chronic lung diseases and chronic neurological disease, the same patients had more than one comorbidity. (BULLETIN No. 32, 2020)

Therefore, this research aims to analyze the cases reported by Covid-19 in the municipality of Glória do Goitá, in the state of Pernambuco, in 2020.

\section{Methodology}

This is an epidemiological study of the descriptive type of documentary research and analysis of secondary data from epidemiological surveillance of the Epidemiological Bulletin of December 28, 2020, conducted in the period of May 2020, in the municipality of Glória do Goitá, in the State of Pernambuco, about the reported cases of Covid-19.

\section{Study site}

The municipality of Glória do Goitá is located in the State of Pernambuco, in the territory of the Zona da Mata Norte, with approximately 30,847 inhabitants with a territorial area of $234,214 \mathrm{~km}^{2}$. The municipal office has a temperature ranging from $21^{\circ} \mathrm{C}$ to $32^{\circ} \mathrm{C}$, with remnants of Atlantic Forest. Its Human Development Index was 0.640 in 2010 (IBGE, 2017). The average concentration of income distribution has a Gini index of 0.5287 (UNDP, 2010) with $16.55 \%$ of the population on the poverty line, denoting marked social inequality (IBGE, 2010). Figure 01.

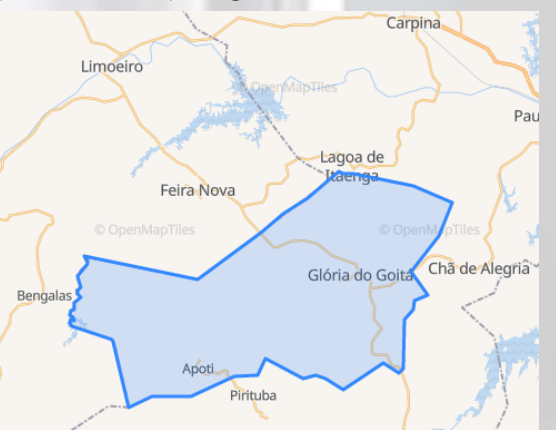

Figure 01. Municipality of Glória do Goitá/PE. Source: https://cualbondi.org/br/a/r303732/gloria-do-goita/

\section{Study population}

The study population consisted of reported cases of Covid-19 in the municipality of Glória do Goitá, in the state of Pernambuco, in 2020.

\section{Data source}

In this study, the analysis of consolidated secondary data by epidemiological surveillance in the Epidemiological Bulletin of December 28, 2020 was applied.

\section{Data analysis}

Being useful in the process of organizing, tabulations and data analysis the computer tool, respectively: Microsoft ${ }^{\circledR} \quad$ Excel 2016 ${ }^{\circledR} \quad$ version 14.0.7183.5000 (MICROSOFT, 2016). 


\section{Results and Discussion}

According to the data consolidated in Epidemiological Bulletin No. 32, published on December 28, 2020, the municipality of Glória do Goitá, located in the state of Pernambuco accumulated until epidemiological week 52, a total of 454 reported cases of COVID-19 and 30 deaths. The distribution of these cases and deaths per epidemiological week is shown in Figure 2.

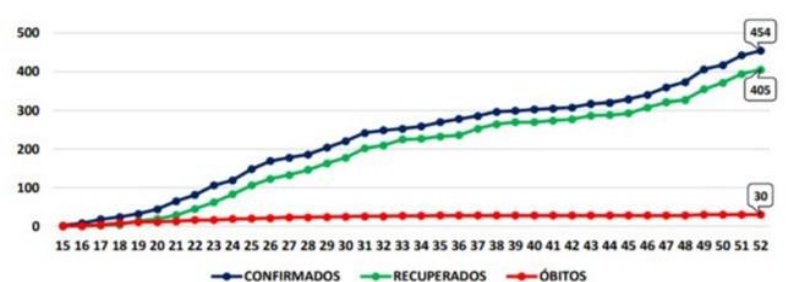

Figure 2. Evolution of Covid -19 cases per Epidemiological Week. Source: Bulletin No. 32 COVID-19 Municipal Health Department, 2020

It was observed that an exponential growth from the 27 weeks without a decrease for the next few weeks, followed by a peak of cases in the epidemiological week of number 52 . The exponential growth in the number of confirmed cases for Covid-19 is presented from epidemiological week 25 , justifying the increase in confirmed cases after lockdown relaxation.

Regarding the number and percentage of confirmed cases of Covid-19, in the municipality of Glória do Goitá, males have a total of $52 \%$ of confirmed cases, while the number and percentage of confirmed cases of Covid-19 in females is $48 \%$. This information corroborates the study conducted by Chen et al., (2020), which can prove that male individuals are in a greater situation of exposure to Covid-19 infection, still being considered socially and culturally responsible for the sustainability of homes. Opportunistic greater episodes of exposure to the virus.

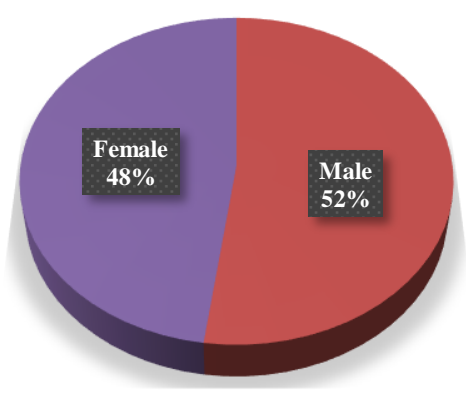

In relation to the analysis of the historical series of the accumulated number of cases per day, it is possible to identify four periods with distinct growths. The representation of the series with the projection until epidemiological week 52 is presented in Figures 3.

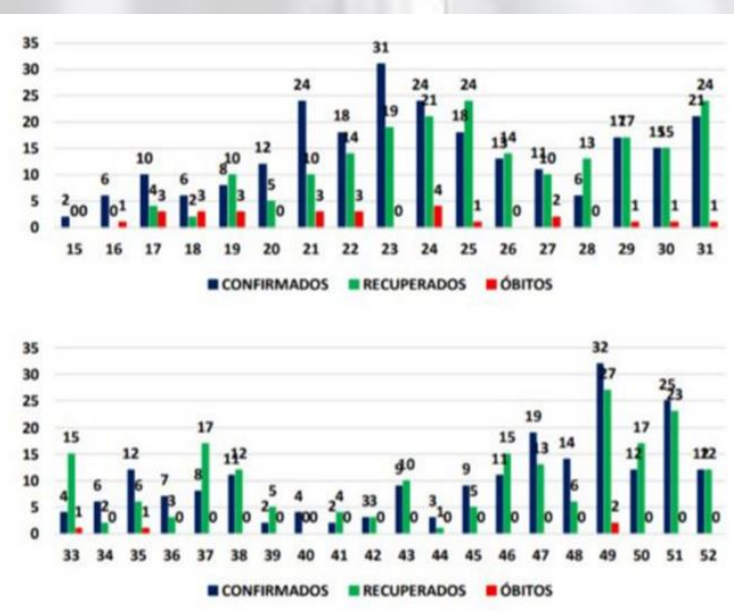

Figure 3. Projection of the accumulated number of reported cases of Covid-19 in the municipality of Glória do Goitá, Pernambuco, per epidemiological week, with projection until epidemiological week 52. Source: Bulletin No. 32 COVID-19 Municipal Health Department, 2020.

In relation to the initial days of the pandemic, the columns of confirmed cases do not present a growth pattern. In the column representing week 21 , the number of confirmed cases totals 24 cases. However, epidemiological week 23 exceeds the level, growing from 24 cases to 31 confirmed cases. The confirmation of deaths due to Covid19 continues to follow the epidemic pattern in the first months of pandemic. Deaths were recorded in the respective epidemiological weeks - 16, 17, 18, 19, 21.24, 25, 27, 29. As of July 30th, we had a cumulative 250 cases. From the evolution of the cases, one can follow the spatial distribution of confirmed, recovered cases and deaths occurred. Study conducted by Souza et al. 2020, points out that after the intraurban propagation of SARS-CoV-2 was strengthened by the accelerated "periferization" of viral transmission in a period considered short.

According to data published in Bulletin No. 32 COVID19 Municipal Health Department 2020, the month of June presented a total of 85 recovered, followed by the month of December, to which presented a total of 78 recovered. Figure 4. And in relation to deaths recorded during the year 2020 , the month of May has the highest mortality rate, 10 deaths, while the months of September and October do not present records of death by Covid-19. Figure 5 .

Graph 1. Number and percentage of confirmed cases of Covid-19, in the municipality of Glória do Goitá, Pernambuco, by sex in the period of 2020. Source: Bulletin No. 32 COVID-19 Municipal Health Department, 2020 . 
4 Bruce, J.C.S.; Lima, A.F.P.S.; Silva, E.T.B.; Silva, E.B.; Lima, J.B.A.S.; Silva, A.S.; Bacelar, E.S.; Santos, A.A.F.; Santos, E.M.L.T.; Bezerra, J.G.; Silva, M.T.B.; Alves, T.E.S.; Alvares, E.B.S.O. Epidemiological analysis of the reported cases of covid-19 in the municipality of Gloria de Goitá, in the state of Pernambuco, in the period of $2020 \ldots$

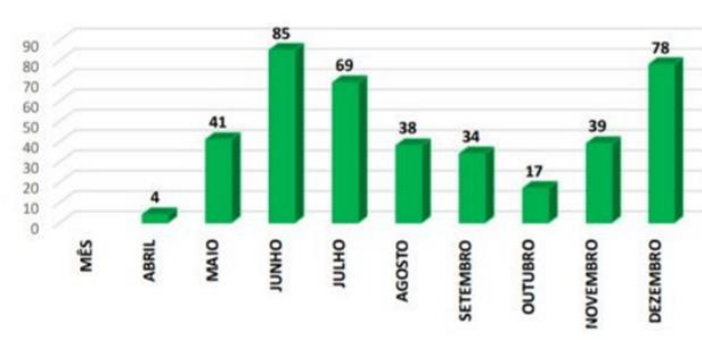

Figure 4. Projection of the number of cases recovered from Covid19 in the municipality of Glória do Goitá, Pernambuco, per month, in 2020. Source: Bulletin No. 32 COVID-19 Municipal Health Department, 2020.

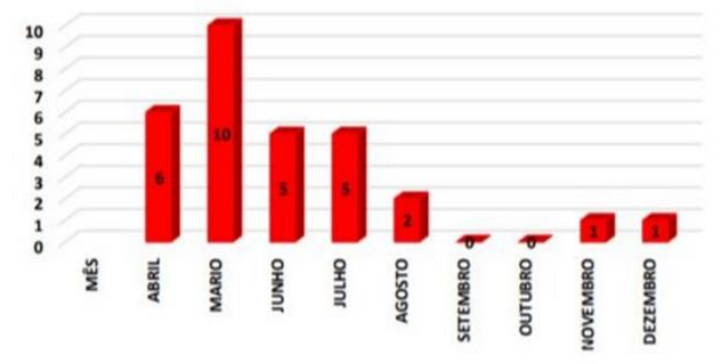

Figure 5. Projection of the number of deaths recorded by Covid-19 in the municipality of Glória do Goitá, Pernambuco, per month, in 2020. Source: Bulletin No. 32 COVID-19 Municipal Health Department, 2020.

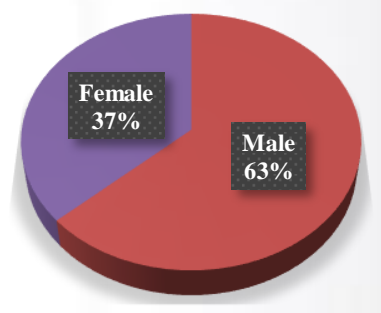

Graph 2. Number and percentage of confirmed deaths of Covid-19, in the municipality of Glória do Goitá, Pernambuco, in the period of 2020 .

Table 1. Projection of the number of cases reported by Covid-19 in the municipality of Glória do Goitá, Pernambuco, rural area and urban area, in 2020.

\begin{tabular}{cc}
\hline Rural Area & Built-up area \\
\hline 55 & 399
\end{tabular}

Source: Bulletin No. 32 COVID-19 Municipal Health Department, 2020.

\section{Conclusions}

From this analysis about the reported cases of Covid-19 in the municipality of Glória do Goitá, in the state of Pernambuco, in the period of 2020, it was found that up to epidemiological week 52, a total of 454 reported cases of COVID-19 and 30 deaths had been reported in the municipality. According to data published in Bulletin No. 32 COVID-19 Municipal Health Department 2020, the month of June presented a total of 85 recovered, followed by the month of December, to which presented a total of 78 recovered. And in relation to deaths recorded during the year 2020, the month of May has the highest mortality rate, 10 deaths, while the months of September and October do not present records of death by Covid-19. Confirming a pattern of infection experienced throughout the national territory.

In addition to publications, this research, in fulfilling its objective, is in line with national policies on epidemiological surveys with the purpose of implementing new prophylactic measures to combat and control this pandemic.

\section{References}

[1] ALMEIDA, Wanessa da Silva de. Mudanças nas condições socioeconômicas e de saúde dos brasileiros durante a pandemia de COVID-19. Rev. Bras. epidemiol. 23 2020. Disponível em: https://www.scielo.br/j/rbepid/a/w8HSZbzGgKCDF HmZ6w4gyQv/abstract/?lang=pt\# Acesso: 15 de maio de 2020.

[2] BRASIL, Ministério da Saúde. Portaria nº580, de 27 de março de 2020. Disponível em: https://bvsms.saude.gov.br/bvs/saudelegis/gm/2020/ prt0580_30_03_2020.html Acesso: 15 de maio de 2020.

[3] CASTRO, CS. et al. Pandemia de COVID-19: Cenário do sistema de saúde brasileiro para o enfrentamento da crise. Pesquisa, Sociedade e Desenvolvimento. [S. 1.], v. 9, n. 7, pág. e516974383, $2020 . \quad$ Disponível em: https://rsdjournal.org/index.php/rsd/article/view/438 3 Acesso: 15 de maio de 2020.

[4] CHEN, N. et al. Características epidemiológicas e clínicas de 99 casos de novos casos de pneumonia por coronavírus em Wuhan, China: um estudo descritivo. Lanceta. 2020.Disponível em:

https://www.thelancet.com/journals/lancet/article/PI IS0140-6736(20)30211-7/fulltext Acesso: 15 de maio de 2020.

[5] GOVERNO DO ESTADO DE PERNAMBUCO. Decreto $\mathrm{n}^{\circ}$ 48.809, de 14 de março de 2020. Regulamenta, no Estado de Pernambuco, medidas temporárias para enfrentamento da emergência de saúde pública de importância internacional decorrente do coronavírus, conforme previsto na Lei Federal $\mathrm{n}^{\circ} 13.979$, de 6 de fevereiro de 2020. Diário Oficial do Estado de Pernambuco 2020; 14 março de 2020.

[6] GUO, Y. et al. A origem, transmissão e terapias clínicas sobre surto de doença coronavírus em 2019 
(covid-19) - uma atualização sobre o status. Military Med Res. 2020, 7: 11. Disponível em: https://pubmed.ncbi.nlm.nih.gov/32169119/ Acesso: 15 de maio de 2020.

[7] LIMA, Luana Hantequestt de et al. Dados epidemiológicos sobre embolia e trombose arterial no Paraná em tempo de covid-19. Revista Uningá, [S.1.], v. 57, n. S1, p. 025-026, jan. 2021. ISSN 2318-0579. Disponível em: http://revista.uninga.br/index.php/uninga/article/vie w/3862 Acesso: 15 de maio de 2020.

[8] MINISTÉRIO DA SAÚDE. Plano de Contingência Nacional para Infecção Humana pelo novo Coronavírus COVID-19. Disponível em:

[9] ORSI, FA. et al. Orientação sobre diagnóstico, prevenção e tratamento das complicações tromboembólicas no covid-19: um documento de posicionamento da Sociedade Brasileira de Trombose e Hemostasia e de Comitê de Trombose e Hemostasia da Associação Brasileira de Hematologia, Hemoterapia e Terapia Celular. Disponível em: https://www.scielo.br/j/htct/a/RpxrHydYQ7KhPRws JrbCCKL/?lang=en Acesso: 15 de maio de 2020.

[10] SOUZA, Wayner Vieira de, et al. Cem dias de COVID-19 em Pernambuco, Brasil: a epidemiologia em contexto histórico. Disponível em: https://scielosp.org/article/csp/2020.v36n11/e00228 220/pt/\# Acesso em: 28 de julho 2020. 